\title{
Study on Determinant Factors of Economic Feasibility in Generating Wind Power in Northeast Brazil
}

\author{
Antônio Henriques de Araujo Junior \\ Department of Production Engineering, Rio de Janeiro State University, \\ Rio de Janeiro, Brazil \\ anthenriques2001@yahoo.com.br \\ Jose Glenio Medeiros de Barros \\ Department of Production Engineering, Rio de Janeiro State University, \\ Rio de Janeiro, Brazil \\ glenio.barros@gmail.com \\ Nilo Antonio de Souza Sampaio \\ Department of Mathematics, Physics and Computing, Rio de Janeiro State University, \\ Rio de Janeiro, Brazil \\ nilo.samp@terra.com.br \\ Luiz de Freitas Ayres \\ Department of Production and Systems, University of Minho, \\ Braga, Portugal; \\ id6889@,alunos.uminho.pt \\ Bernardo Bastos da Fonseca; \\ Department of Production Engineering, Rio de Janeiro State University, \\ Rio de Janeiro, Brazil \\ bernardobastosf@gmail.com \\ Maria da Gloria Diniz de Almeida; \\ Department of Production Engineering, Rio de Janeiro State University \\ Rio de Janeiro, Brazil \\ Gloria_uerj@yahoo.com.br
}

\begin{abstract}
Wind energy is an additional source of renewable energy, those energies that do not harm the environment and fits in the group of alternative energies. Brazil has one of the cleanest energy matrices in the world, mainly a matrix based on hydro power. The country is considered the most promising market for wind energy in Latin America, with an estimated wind potential of $300 \mathrm{GW}$. The research aimed to identify and define variables that most strongly impact the economic viability of operating equipment and wind farms in Northeast Brazil, identifying the key performance factors for the economic analysis performed, such as technologies, equipment size and productive efficiency. The study focused on wind turbines with installed capacity above $1 \mathrm{MW}$, capable of generating power at more competitive costs. Deterministic models were used in the analysis of investment projects, which included the elaboration of the Discounted Cash Flow (DCF) and the adoption of indicators such as Net Present Value, Internal Rate of Return and Pay-back, complemented with a sensitivity analysis of the main variables impacting the economic viability of wind investments in Northeast Brazil. The cash flow analysis allowed the calculation of the break-even for the different variables analyzed, equipment load factor, wind turbine investment and effective hours available for wind generation, among others. Although for the situation analyzed, wind generation projects in the Northeast of Brazil are economically viable, the profitability of these projects for the assumptions of the calculation assumed is still low, considering they generate a 15 year Pay-back and a return rate of $9.22 \%$ as opposed to an assumed financing cost of $7,3 \%$ p.a.
\end{abstract}




\section{Keywords}

Wind energy, Feasibility study, Generating wind power in Northeast Brazil

\section{Introduction}

Gradually, the traditional sources of energy generation are being exhausted in Brazil. The progressive use of water resources in the South, Southeast and Midwest has shifted energy production to regions farthest from major industrial and urban centers, increasing the costs of energy generation, transportation and distribution. Thus, in this sense, the generation of wind energy emerges as an important complementary alternative when compared with traditional sources such as hydro and thermoelectricity. For this reason, in recent years, there has been a strong increase in energy generation in Brazil with alternative sources such as wind and solar energy; between the years 2016 and 2017 there was a $20 \%$ increase in wind power generation, corresponding to an addition of 15.6 TWh (ABEEOLICA, 2018) increase in wind power generation, corresponding to an addition of $15.6 \mathrm{TWh}$ (ABEEOLICA, 2018). Currently, the wind power generated in Brazil is enough to supply about 20 million homes. In 2015 alone, more than 100 wind farms started operating in Brazil, with about 5,2 billion USD in investments generating 41 thousand jobs (EPE, 2018).

This expansion is attracting large international companies that are betting on the growth of this type of energy in Brazil, being currently the fourth country in the world in what concerns the growth of wind energy. Among all modalities, it was the one that grew the most in 2017, in comparison to other sources of electricity generation. According to the Brazilian Ministry of Energy, in 2017, wind energy represented 8.3\% of the Brazilian energy matrix of which, in relation to installed capacity, Brazil is currently ranked $8^{\text {th }}$ in the world ranking. Another 213 wind farms are expected to be additionally in operation in operation in2023, which is expected to make Brazil, one of the six largest producers in the world, in this type of energy. Thus, to support the decision to invest in the expansion of wind power generation in Brazil, it was proposed to carry out a comprehensive study considering aspects of the technical and economic feasibility of wind power generation to subsidize this decision.

\subsection{Perspective of wind power generation in Brazil}

Brazil has one of the cleanest energy matrices in the world, mainly a matrix based on hydro power. The country can be considered the most promising market for wind energy in Latin America, with an estimated wind potential of $300 \mathrm{GW}$ (some analysts consider even a potential of $500 \mathrm{GW}$ ) and the energy demand is expected to increase by $2 \mathrm{GW}$ per year until 2020. Moreover, wind conditions in Brazil are characterized as strong and stable. The focus on the Brazilian wind energy sector is mainly onshore, due to lower cost and land availability and sector specialists do not foresee a promising future for offshore wind energy in Brazil within the next 10 to 20 years.

One decade ago, more than $80 \%$ of the electricity generation installed capacity was linked to sustainable sources due mainly to 158 operating hydraulic plants operating in Brazil; Brazil's fundamental energy model has long been based around hydroelectric power and even today, $70 \%$ of Brazil's renewable electricity still comes from large hydraulic sources, like the Itaipu hydroelectric dam, the second largest in this type in the world.

The development of new hydro plants can no longer be maintained due to geographical circumstances, strong climate change in the last decade and strict environmental regulations, which led the Brazilian government to shift its focus towards renewable energy sources. In this way, Brazil tries to diversify electricity production away from hydropower. In this sense, specialists point to a growth of the wind energy participation in Brazil's energy matrix. This segment which is already responsible for $8.3 \%$ of the energy produced in the country, a percentage still far from the $70 \%$ produced by hydroelectric plants. but already close to the $9.3 \%$ of biomass plants production, occupy the second place in the national energy ranking.

\subsection{Research objectives and delimitation of the research object}

The proposed research aims to identify and define variables that most strongly impact the economic viability of operating equipment and wind farms in Northeast Brazil, identifying the key performance factors for the economic analysis performed, such as technologies, equipment size and productive efficiency. The study focused on wind turbines with installed capacity above $1 \mathrm{MW}$, capable of generating power at more competitive costs. The research 
was limited to Northeast Brazil, and more specifically to the federal State of Ceara, by its wind potential in the coastal region of this State and by extensive surveys and studies carried out by local governmental planning institutions and the State University of Ceara (UFC).

\section{Literature Review}

Wind energy is the most cost competitive renewable energy source. Onshore wind energy is cheaper than any other renewable energy and it is competitive with conventional power generation sources such as coal and gas. When taking into consideration pollution costs and subsidies, which are not included in LCOE (Levelized Cost of Energy) estimations, onshore wind is the cheapest generation source in Europe; offshore wind is on a steady cost reduction pathway with expected costs of $€ 100 / \mathrm{MWh}$ by 2020 and $€ 85$ to $€ 79 / \mathrm{MWh}$ by 2025 . The above forecast, contained in the document 'The Economics of Wind Energy', published by EWEA (GWEC, 2017) has already been surpassed, with wind generation costs in some European countries are currently standing at the level of $€ 50$ Euros/MWh.

According to ABEEOLICA (2028), Brazil occupied the eighth position in the world ranking of accumulated capacity of wind generation (14.7 MW) in 2017, surpassing Canada (12.3 MW) with projections to reach an installed capacity of $19.4 \mathrm{MW}$ in 2023 , which refer in this situation to contracts made possible in auctions already carried out and to be negotiated, in the spot market in the near future. Brazil has been very proactive in renewable sources, both wind and solar, and has an ambitious program to increase this share of wind energy in the country's energy matrix. Among the top ten wind energy producers in the country, the three largest are located in Northeast Brazil, respectively in the Brazilian federal states of Rio Grande do Norte, Bahia and Ceara.

\subsection{Studies and papers published about wind energy feasibility studies}

Several studies and papers have been internationally published about feasibility studies of wind generating projects, especially in the last decade. For the purposes of this study, an extensive bibliographical research was carried out on the theme "Studies on Economic Viability of Wind Projects", as shown in Table 1. The researched period covered a period of 34 years (1985-2019), starting with a pioneering work "Study of Wind Energy Utilization in Saudi Arabia", conducted in 1985 (Amin \& El-Samannoudy, 1985). Among these papers and technical studies, there are technical and economic feasibility studies both related to onshore and offshore generation; these also address the feasibility of both small equipment to be used in agricultural activities and large wind farms with large wind generating equipment, contemplating different techniques and analysis methods: conventional deterministic models using traditional indicators such as Net Present Value and Internal Rate of Return and more sophisticated analysis using Monte Carlo models for electric energy demand estimates. Part of the papers analyzed are shown in Table 1, where the publications made in Brazil and abroad were intentionally mentioned separately.

Feasibility studies that have been published analyze details such as siting, permits, grid interconnection and energy output in connection to meteorological conditions. There are a variety of models available for calculating the feasibility of utility scale projects, however, small wind projects lack feasibility analysis of a general model. Komarek (2007) estimated costs of generating wind energy with small wind systems in the Michigan agriculture, defining for this study small wind turbines, defined as those with $100 \mathrm{~kW}$ or less. According to the author (...) small scale wind equipment can play an important role in the sustainability of Michigan's agriculture sector and can potentially increase farm profits and decrease incentives to convert farmland to non-farm uses." The author besides, stated that (...) most of the past literature concerning small wind energy is based on site specific studies". The author also mentioned that his study intended to provide an integrated general model for analyzing the feasibility of small wind energy projects, specifically using policy options as available to Michigan agriculture producers. Khambalkar et al. (2007) published in 2007, research concerning a 2 MW installed capacity Wind Power Project, conducted in the Indian state of Maharashtra. The main objective of the research was to evaluate various costs involved in the energy production.

The cost of energy production per kWh was calculated for the first year of operation. The economics of wind energy and thereby the feasibility of the power project were examined by estimating the per unit cost of energy, evaluating the feasibility of this project using the traditional methods such as Net Present Value (NPV), Benefitcost ratio (B-C), Internal Rate of Return (IRR), and Pay-back period. In this wind energy conversion project, three costs: the installed capital cost, specific capital cost, and life cycle cost of energy, were examined for the evaluation 
of the production cost of the energy generated. Considering the discount rate on the investment for the project as 7.5 percent, the B-C ratio came to 3.51 and the IRR to $21.82 \%$. Oliveira and Fernandes (2015) used in this paper cost effectiveness indicators for economic cost analysis of wind projects by discussing the concept of Levelized Cost of Energy (LCOE) and proposing the application of the Total Life-Cycle Cost (TLCC) method to wind energy projects. For each indicator studied it was pointed out, in this paper, the project bottlenecks and its application, in the evaluation of wind energy projects.

Table 1: Papers and Studies published in Brazil and Internationally on Wind Generation Feasibility Studies

\begin{tabular}{|c|c|c|}
\hline Papers and Studies & Authors & \begin{tabular}{|c|} 
Publication \\
Year
\end{tabular} \\
\hline \multicolumn{3}{|l|}{ Internationally published } \\
\hline 1. Feasibility Study of Wind Energy Utilization in Saudi Arabia & Amin, El-Samannoudy & 1985 \\
\hline 2. FLOAT -Technical and economic feasibility of a floating wind turbine & Quarton \& Hassan & 2003 \\
\hline \multirow[t]{2}{*}{ 3. Wind Energy Cost and Feasibility of a 2 MW Wind Project } & Khambalkar, Gadge, & 2007 \\
\hline & Dahatonde \& Karale & \\
\hline 4. Economic Feasibility Evaluation of Small Wind Systems in Michigan Agriculture & Komarek & 2007 \\
\hline 5. Feasibility Study of Developing Wind Power Projects in Iceland: An Economic Analysis & Jónasson & 2008 \\
\hline 6. Energy return on investment (EROI), economic feasibility and carbon intensity of a & Endres & 2008 \\
\hline \multicolumn{3}{|l|}{ hypothetical Lake Ontario wind farm } \\
\hline 7. Wind Feasibility Study & Clark & 2009 \\
\hline 8. Economic Feasibility Applied to Wind Energy Projects & Olive ira, Fernandes & 2011 \\
\hline 9. Cost-effectiveness Analysis for Wind Energy Projects & Olive ira, Fernandes & 2012 \\
\hline 10. Economic feasibility analysis of a wind farm in Caldas da Rainha, Portugal & Olive ira, Fernandes & 2013 \\
\hline 11. Feasibility Study of Economics and Performance of Wind Turbine Generators & Roberts \& Mosey & 2013 \\
\hline \multicolumn{3}{|l|}{ at the Newport Indiana Chemical Depot Site } \\
\hline 12. Economic Cost Evaluation on the Viability od Offshore Wind Turbine Farms in Nigeria & \begin{tabular}{|l|} 
Effiom, Nwankwojike, \\
Abam
\end{tabular} & 2016 \\
\hline 13. Life Cycle Cost-benefit Analysis of Offshore Wind Energy under the Climatic & Nian, Liu \& Zhong & 2019 \\
\hline \multicolumn{3}{|l|}{ Conditions in Southeast Asia - Setting the bottom-line for Deployment } \\
\hline \multicolumn{3}{|l|}{ Published in Brazil } \\
\hline $\begin{array}{l}\text { 14. "Conceptual Project and Economic Feasibility Analys is of Wind Power Generation Unit } \\
\text { in Lagoa dos Patos, RS, Brazil" }\end{array}$ & Garbe \& Tomaselli & 2010 \\
\hline 15. Economic Feasibility Analysis of Wind Generation Projects in Brazil & Simis & 2010 \\
\hline 16. "Application of the Activity-Based Costing (ABC) method for the & Sanford & 2012 \\
\hline \multicolumn{3}{|l|}{ costing of wind farm projects" } \\
\hline 17. "Study of the Technical Feasibility for the implantation of Wind Farm in the Southwest & Rossoni & 2013 \\
\hline \multicolumn{3}{|l|}{ Microre gion of Paraná and West of Santa Catarina, Brazil" } \\
\hline 18. Analyses of Wind Energy in the Electrical Scenario: General Aspects and Indicators & Gomes \& Henkes & 2015 \\
\hline \multicolumn{3}{|l|}{ of Economic Viability } \\
\hline 19. "Analysis of economic and financial viability and risk evaluation of a wind project with & Macedo, Albuquerque, & 2017 \\
\hline Monte Carlo simulation" & Morales & \\
\hline
\end{tabular}

Effiom et al. (2016), published research work about an economic cost evaluation on the economic feasibility of producing energy with offshore wind turbine, in Nigeria, using a 500 MW OWT (Off Shore Wind Turbine) farm. A developed model was used in this research to evaluate the economic cost of an OWTs at different phases of the project. Additionally, the effect of the cost drivers at the changed phases of the OWTs was studied correspondingly. Results obtained showed that over $50 \%$ of the OWT project cost emanated from capital expenditure while a value less than $50 \%$ came from operating expenditures. However, further analysis indicated at a maximum power of $4 \mathrm{MW}$, a $4.95 \%$ diminution in LCOE.

And finally Nian, Liu and Zhong (2019) conducted an interesting study on offshore generation discussing the technical and economic conditions in Southeast Asia and putting this mode of renewable energy resource as an option to address a country's energy and climate objectives without having to occupy large amount of land space. The authors reported in this paper that (...) wind conditions in Southeast Asia are generally much less favorable as compared to other parts of the world, although several economies in this region consider offshore wind energy as a long term solution to decarbonize the electricity sector and to diversify the source of electricity".

There is according to the above authors (...) a need to evaluate the true benefits of offshore wind energy under the region's suboptimal climatic conditions." This study employed the Life-cycle analysis to conduct a Costbenefit analysis of offshore wind energy in the Southeast Asia context. Findings from the study suggested that the offshore wind energy cost still remained high at that moment of the research for this Asian region. 


\section{Methodology and Methods}

\subsection{Methodology and Methods used in the research}

The elaboration of a research project and the development of the research itself, be it a dissertation or thesis, should obtain results to be satisfactory, and should be based on a careful planning, solid conceptual reflections and grounded in existing knowledge. Research is a work in progress that is not fully controllable or predictable. Adopting a methodology means choosing a path, a global course of the spirit. The route often requires reinventing at each step. We need, then, not only rules but a lot of creativity and imagination to perform this work. Scientific research depends on a "set of technical procedures" to achieve its objectives. In this sense, we can understand Scientific Method as the set of processes or intellectual operations that must be used in the investigation.

Lakatos and Marconi (1993) by mentioning the logical bases on which such methods are based mention the main methods that provide the logical basis for research: deductive, inductive, hypothetical-deductive, dialectical, and phenomenological. From the point of view of its nature, this research is an Applied Research that is the one that aims to generate knowledge for practical application, directed to the solution of specific problems, a Qualitative Research, the type of research that requires the interpretation of phenomena and where the attribution of meanings does not necessarily require the use of statistical methods and techniques. It is also a research, in which the researcher tends to analyze its data and processes focusing on the process and its meaning.

\subsection{Methods employed in the Research}

The field research for data collection was preceded by extensive library and bibliographic research on the following topics: wind energy economics, wind energy costs, operation and maintenance costs of wind turbines, economic feasibility studies on the wind generation, Brazilian wind energy market and Brazilian renewable energy market. A Bibliographical and Bibliometric research was performed using the following data bases: Google Scholar, Directory of Open Access Journals, Open Library, SpringerLink, besides the repositories of the Portuguese Minho and Porto universities. Deterministic models were used in the analysis of investment projects, which included the elaboration of the Discounted Cash Flow (DCF) and the adoption of indicators such as Net Present Value, Internal Rate of Return and Pay-back, complemented with a sensitivity analysis of the main variables impacting the economic viability of wind investments in Brazil and Portugal.

The Cash Flow analysis allowed the calculation of the break-even for the different variables analyzed, equipment load factor, wind turbine investment and effective hours available for wind generation, among others. The economic viability analysis of wind power equipment in this study considered the income tax legislation and accounting legal depreciation as practiced in Brazil. Concerning the Brazilian legislation, the depreciation of wind generators, its depreciation rate and depreciation period are still under study, and for this reason it was adopted in this study a depreciation period of 10 years equivalent to that of hydraulic turbines (code 8410 of the Brazilian federal revenue service). Although wind equipment at the end of a considered useful life of 20 years, still has residual value and incur expenses for disposal (wind turbines made of composite material, fiberglass and wood laminate) must be dismantled and destroyed with special environmental care), these revenues and expenses due to calculation difficulties and because they not strongly impact the cash flow, were not considered in the Cash Flow simulation.

\subsection{Research Data Sources}

The data for the elaboration of Cash Flows under the conditions of economic analysis in Northeast Brazil, such as investment in the acquisition of wind generators, civil engineering costs in infrastructures (foundations, access roads, electrical connections, etc.), wind generators load factors, wind conditions, Brazilian IRS taxes, tariffs, among others, were obtained from different sources:

- Equipment working hours and power of wind turbines, load factor, average tariffs practiced in energy auctions in Brazil were obtained from the document "Installed generation capacity in the Brazilian electricity system", published by the Ministry of Mines and Energy of Brazil, in June 2018 (BRAZILIAN MINISTRY OF MINES AND ENERGY, 2018);

- Information related to the wind conditions of the State of Ceara, Brazil, its speeds and distributions were obtained in SEINFRA (2019) - in the document "Atlas Eólico do Estado do Ceara" ('Wind and Solar Atlas of the State of Ceara'), published May 2017; 
- Numerous technical bulletins from the Brazilian Wind Energy Association, ABEEOLICA (2018) were consulted in the context of this research;

- Other documents produced outside Brazil, such as "Market study: Wind energy in Brazil" Ministry Of Economic Affairs In The Netherlands (2014), were also consulted.

\subsection{Analysis Framework for Wind Energy}

For the calculation of project returns, its viability, regulatory and legal framework must be analyzed in accordance with the specific conditions of the region and the country. Country-specific conditions for the development of wind energy projects are based upon the policy framework conditions prepared by national or regional governments. The financial feasibility of any wind energy project proposed to sell electricity to the grid depends on the available framework conditions for support. Inadequate or non-existent framework conditions often form crucial barriers impeding the exploitation of available wind energy potential. According to GTZ (2002), the existence, operability and reliability of a feed-in tariff system must be checked and integrated in the financial viability assessment.

\section{Cash Flows and Results Discussion}

\subsection{The Cash Flow calculation}

The economic analysis was performed using conventional Cash Flows, which considered parameters as used in traditional economic viability deterministic models, such as Net Present Value (NPV), Internal Rate of Return (IRR) and Pay-back followed by a sensitivity analysis of the variables; additionally, we have adopted the US Dollar as our monetary reference. In the case of amounts originated in Brazilian currency Real, these were converted into the American currency at the parity on the date they were generated. In order to analyze the economic viability of wind power projects, in Northeast Brazil, in context of this research, three cash flows were elaborated, considering technical and tax aspects:

- Cash Flow 1 according to Brazilian technical and tax parameters, 20-year life span and 20-year straight-line depreciation period;

- Cash flow 2 according to Brazilian technical and tax parameters, 20-year life span and a10-year straight-line depreciation period.

- Cash flow 3 according to Brazilian technical and tax parameters and a 5-year straight-line depreciation period;

The above three cash flows show the main differences among the cash flows considered in the economic feasibility analysis of wind generating projects in Northeast Brazil consisting the main differences between these flows, in the project lifecycle and in the equipment depreciation. Although there is a difference in relation to the cost of wind turbines and civil works in projects being implemented in Brazil, in the absence of detailed data and more precise budgets, we have adopted international values for the implementation of wind power projects in Northeast Brazil.

\subsection{Wind Generating Projects and Financing Conditions in Northeast Brazil}

\subsubsection{Interest and financing rates}

Projects financed by the Brazilian BNDES ('National Bank for Economic and Social Development') consider in its financial cost a basic rate for long-term projects called TJLP (Long-term Interest Rate), the quarterly interest rate, which is currently equivalent to $6.5 \%$ yearly. For direct operations, the final interest rate is made up of the financial cost and the BNDES rate (including the bank remuneration and the credit risk rate):

Interest Rate $=$ Cost Factor $x$ BNDES Rate Factor -1

Let's consider the example:

Financial cost $=6 \%$ p.a.; BNDES rate $=1.3 \%$ p.a.

Financial Cost Factor $=1.06$; BNDES Rate Factor $=1.013$.

Interest rate $=1.06 \times 1.013-1=7.3 \%$ p.a.

For indirect operations, the final interest rate is composed of the Financial Cost, the BNDES Rate (including the remuneration of the National Brazilian BNDES and the financial intermediation rate) and the Financial Agent Rate, being made up of the following equation:

Interest Rate $=($ Cost Factor $\mathrm{x}$ 'BNDES' Rate Factor $\mathrm{x}$ Agent Rate Factor $)-1$ 
Let us consider the following example:

Financial cost $=6 \%$ p.a.; BNDES Rate $=1.3 \%$ p.a.; Agent Rate $=3 \%$ p.a.

Financial Cost Factor $=1.06$; BNDES Rate Factor $=1.015$; Agent Rate Factor $=1.03$

In this case, the BNDES interest rate is calculated as:

Interest rate $=1.06 \times 1.013 \times 1.03-1=10.6 \%$ p.a.

According to the Sectorial Chamber of renewable energies of the Federation of Industries of the State of Ceara (FIEC), the financing rates follow the same financing rules as those of the BNDES and vary according to the company's project rating and payment capacity, location and default factor (the latter factors concerning Northeast Brazil). Additionally, a risk rate is included, which considers the transaction conditions and the and the economic and equity situation of the loan borrower.

At the interest rate adopted for this study, a BNDES interest rate of $6 \%$ p.a. and a BNDES rate factor of $1.3 \%$ p.a. were considered, and without an intermediary economic agent in the operation, it would result in a wind project financing rate of $7.3 \%$ p.a., adopted in this research.

\subsection{Total Funding Period}

The amortization period is determined according to the capacity of payment of the enterprise, the client or the economic group, respecting the maximum limit of 24 years. In the case of 'Banco do Nordeste do Brasil' (BNB), they follow the conditions of the Constitutional Financing Fund of the Northeast - FNE for Infrastructure: Interest rate

$\mathrm{IPCA}+1.2765 \%$ a.a.

The total funding period is up to 20 years

Both development agents require real guarantees such as: mortgage, pledge, fiduciary property, receivables, etc. defined in the analysis of the operation.

\subsection{IRS rate in Brazil}

In the Brazilian case, an individual investor rate of $27 \%$ was adopted.

\subsection{Revenue generated and expected tariffs}

The revenues generated by the wind farms considered for the purposes of the study, a total of 8,760 annual hours and a load factor of $50 \%$, in the case of wind farms installed in Brazil. An average tariff of 31 (USD/MWh) according to EPE (2018) was considered. A progressive increase in wind power tariffs expected for the Brazilian energy market should make wind power generation in Brazil even more attractive from an economic point of view.

\subsection{Other information regarding Cash Flows}

The economic feasibility of stand-alone machine/equipment for wind generation was considered, due to the complexity of the analysis of wind farms. In the absence of specific information regarding the acquisition cost of wind generators, it was taken as a reference a $3 \mathrm{MW}$ wind turbine with an estimated investment of US\$ 1.5 million for the generation scenarios in the northeast of Brazil. For deployment and infrastructure costs, a ratio of $25 \%$ of total costs was adopted, a parameter adopted internationally. Thus, an investment of US\$ 2.2 million was adopted for the total implementation costs of a wind generator. The equipment maintenance cost considered was $1.5 \%$ of the equipment acquisition costs per year for the first 10 years of operation and $2.0 \%$ from the eleventh year to the twentieth year. The scenario that was taken as reference for the economic analyses in the Brazilian case was Cash Flow 2, which considered a depreciation of 10 years and a 20 -year life span for the wind equipment.

\subsection{Cash Flow considered for wind energy generation in Northeast Brazil}

We adopted following parameters to the standard Cash Flow considered for the elaboration of economic feasibility of wind energy according to Brazilian financing condition for undertakings in Northeast Brazil:

- Investment interest rate (yearly): 7,3\% p.a.

- Operation and maintenance costs: $1.5 \%$ p.a. for the first 10 years and $2.0 \%$ p.a for the last 10 years

- Annual revenue generated in the assessed period: 407,34 USD

- Tariff: 31 [USD/MWh]

- Wind equipment investment: 2,28 [Million USD] 
- Total investment civil works inclusive: 3,04 [Million USD]

- Depreciation of equipment: 10 years

- Load factor: $50 \%$

- IRS rate: $27 \%$

For the above Cash Flow, of a $3 \mathrm{MW}$ wind power generator whose investment was estimated at USD 2.28 million and infrastructure expenditures at 760 [USD x 1000] and total investment of 3,04 [USD x 1000], considering the parameters shown above, this investment proved to be economical feasible with following indicators: NPV equal USD 457,390 and a IRR of $9.22 \%$. In addition to the elaboration of the investment cash flow, following variables were analyzed: interest rate, load factor, wind turbine investment and wind generation tariff, as shown in Table 2 to Table 5.

Table 2: NPV variation due to the variable 'investment rate' - Wind project in Brazil

\begin{tabular}{|c|c|c|c|c|c|c|c|}
\hline Investment Rate $[\%]$ & $\mathbf{4 , 0}$ & $\mathbf{6 , 0}$ & $\mathbf{8 , 0}$ & $\mathbf{1 0 , 0}$ & $\mathbf{1 2 , 0}$ & $\mathbf{1 4 , 0}$ & $\mathbf{1 6 , 0}$ \\
\hline NPV $[1000$ USD] & $1.543,7$ & 832,3 & 595,7 & $-158,5$ & $-508,4$ & $-792,2$ & $-1.025,1$ \\
\hline IRR $[\%]$ & $9,22 \%$ & $9,22 \%$ & $9,22 \%$ & $9,22 \%$ & $9,22 \%$ & $9,22 \%$ & $9,22 \%$ \\
\hline
\end{tabular}

In Table 2, it can be verified that for interest rates above $9,22 \%$ p.a., the NPV becomes negative and the investment unfeasible; the economic break-even point for this alternative is the internal rate of return itself, $9,22 \%$ p.a.

Table 3: NPV and IRR variation due to the variable 'load factor' - Wind project in Brazil

\begin{tabular}{|c|c|c|c|c|c|c|c|}
\hline Load Factor [\%] & $\mathbf{2 0}$ & $\mathbf{2 5}$ & $\mathbf{3 0}$ & $\mathbf{3 5}$ & $\mathbf{4 0}$ & $\mathbf{4 5}$ & $\mathbf{5 0}$ \\
\hline NPV [1000 USD] & $-2,131.1$ & $-1,221.0$ & -885.3 & -549.6 & -213.9 & 121.7 & 457.4 \\
\hline IRR $[\%]$ & $-1.48 \%$ & $0.94 \%$ & $2.96 \%$ & $4.73 \%$ & $6.34 \%$ & $7,83 \%$ & $9.22 \%$ \\
\hline
\end{tabular}

Table 3 shows the NPV and IRR variation due to 'load factor' (see Appendix 6); considering the set of variables defined for the standard cash flow; the break-even for this variable is reached for a load factor of $43.18 \%$. Under these conditions, a wind project in Brazil will be economically feasible.

Table 4: NPV and IRR variation due to the variable 'turbine investment' - Wind project in Brazil

\begin{tabular}{|c|c|c|c|c|c|c|}
\hline $\begin{array}{c}\text { Wind Turbine } \\
\text { Investment }[\text { USD/MW] }\end{array}$ & $\mathbf{4 0 0 , 0 0}$ & $\mathbf{5 0 0 , 0 0}$ & $\mathbf{6 0 0 , 0 0}$ & $\mathbf{7 0 0 , 0 0}$ & $\mathbf{7 6 1 , 0 0}$ & $\mathbf{8 0 0 , 0 0}$ \\
\hline NPV $[1000$ USD] & $1.832,8$ & $1.451,8$ & $1.070,8$ & 689,8 & 457,4 & 308,8 \\
\hline IRR $[\%]$ & $19,78 \%$ & $15,62 \%$ & $12,65 \%$ & $10,38 \%$ & $9,22 \%$ & $8,55 \%$ \\
\hline
\end{tabular}

Table 5: NPV and IRR variation due to the variable 'tariff' - Wind project in Brazil

\begin{tabular}{|c|c|c|c|c|c|c|}
\hline Tariff $[$ USD/MW] & $\mathbf{2 5}$ & $\mathbf{3 0}$ & $\mathbf{3 1}$ & $\mathbf{4 0}$ & $\mathbf{5 0}$ & $\mathbf{6 0}$ \\
\hline NPV $[1000$ USD $]$ & $-192,30$ & 349,10 & 457,40 & $1.431,90$ & $2.514,80$ & $3.597,60$ \\
\hline IRR $[\%]$ & $6,40 \%$ & $8,78 \%$ & $9,22 \%$ & $12,91 \%$ & $16,64 \%$ & $20,13 \%$ \\
\hline
\end{tabular}

The break-even for the variables 'turbine investment' (Table 4) and 'tariff' (Table 5) was also calculated and following results were obtained: Wind Turbine Investment equal to 881.11 [USD/kW], see Appendix 7, and 26.73 [USD/MW], see Appendix 8, for the variable 'tariff'. 


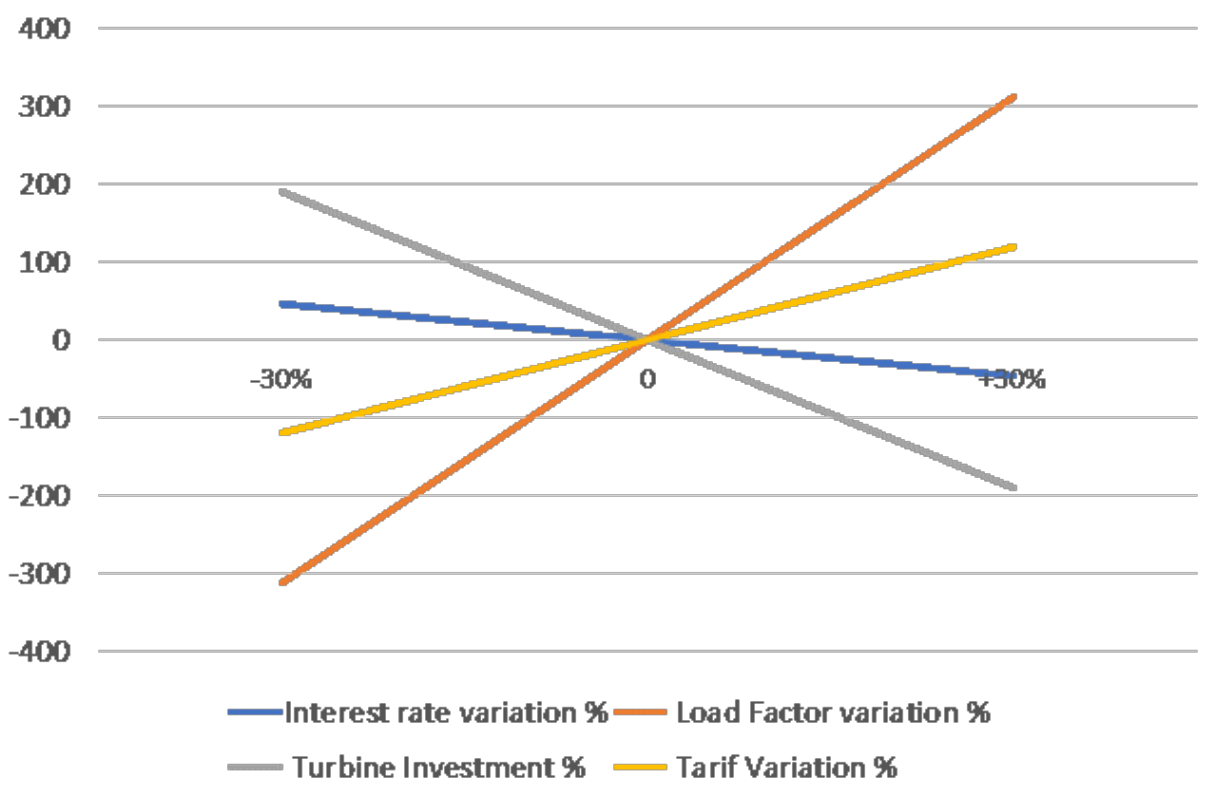

Figure 2: Sensitivity analysis of the variables: Interest Rate, Load Factor, Turbine Investment and Tariff - Cash flow 4 - Wind Investment project in Brazil

Regarding the sensitivity of the variables mentioned above, that is the major or minor impact on the NPV value of the evaluated flows, and as shown in Figure 6.1, the variable with the highest impact is the 'load factor' positively correlated with the NPV followed, in order, by the variables 'turbine investment' (negatively correlated), 'tariff' (positively correlated) and 'interest rate' with negative correlation. The break-even of the variables 'interest rate', 'load factor', 'turbine investment' and 'tariff' are shown in Table 6.10. For the variables 'interest rate' and 'tariff', the break-even for wind projects in Brazil are below the corresponding break-even in similar projects in Portugal. In the case of the load factor and turbine investment variables, the opposite is true.

able 6: Break-even of the variables 'interest rate', 'load Factor', 'turbine investment' and 'tariff' for wind projects in Northeast Brazil

\begin{tabular}{|c|c|c|c|}
\hline $\begin{array}{c}\text { Interest rate } \\
{[\%]}\end{array}$ & $\begin{array}{c}\text { Load Factor } \\
{[\%]}\end{array}$ & $\begin{array}{c}\text { Turbine Investment } \\
{[\mathrm{USD} / \mathrm{kW}]}\end{array}$ & $\begin{array}{c}\text { Tariff } \\
{[\mathrm{USD} / \mathrm{MW}]}\end{array}$ \\
\hline 9.22 & 43.18 & 881.11 & $26.73]$ \\
\hline
\end{tabular}

\section{Conclusion}

This research aimed to analyze the economic viability of wind generation in Northeast Brazil, as well as to define the variables that currently most strongly impact the viability of operating equipment and wind farms, identifying its key economic impact, such as technologies, equipment size and load factor among others. In this context, wind conditions, their intensity, direction, duration, and probability of occurrence was taken from surveys conducted by the Ceara State Secretariat of Infrastructure (SEINFRA) [25] published in the document "Wind and Solar Atlas of Ceara State' provided for this research by the Ceara Federal University. Information for this research was also obtained from technical reports published by ABEEOLICA, EPE (Energy Planning Company) of the Brazilian Ministry of Mines and Energy, as well as information regarding wind project financing conditions, provided by the Federation of Industries of the State of Ceara. Deterministic models were used in the analysis of investment projects, which included the elaboration of Cash Flows and the adoption of indicators such as Net Present Value, Internal Rate of Return and Pay-back, complemented with a sensitivity analysis of the main variables impacting the economic viability of wind investments in Northeast Brazil. The cash flow analysis allowed the calculation of the break-even for the different variables analyzed, equipment load factor, wind turbine investment and effective hours available for wind generation, among others. Although for the situation analyzed, wind generation projects in the Northeast of Brazil are economically viable, the profitability of these projects for the assumptions of the calculation assumed is still low, considering they generate a 15 years Pay-back and a return rate of $9.22 \%$ as opposed to an assumed financing cost of 7,3\% p.a. (BNDES interest rates for the financing of larger wind 
generation projects) and also in view of the risks involved in the projects; in the Brazilian case, tariff fluctuations (due to the auctions practiced), risk in the wind equipment prices due to monetary exchange variations, and even the existence of non-controllable variables such as wind intensity and duration.

For the standard flow considered - Cash Flow 2 - for generation in Northeast Brazil the internal rate of return and the NPV are respectively of $9,21 \%$ yearly (financing BNDES rate 7,3\%) and the $454.136,80 \mathrm{USD}$ ( 20 -year project life span). The sensitivity of the variables 'interest rate', 'load factor', 'turbine investment' and 'tariff', the variables with the greatest impact on the Cash Flows analyzed, were calculated as shown in Table 2 to Table 5 for Brazilian wind projects. Among these, in the Brazilian case, the variable with the highest impact was the 'load factor' positively correlated with the NPV followed, in order, by the variables 'turbine investment' (negatively correlated), 'tariff' (positively correlated) and 'interest rate' with negative correlation. We simulated the impact of depreciation on wind projects for Northeast Brazil with the following result: depreciation extended to the 20-year analysis horizon for standard Cash Flow results into an NPV of USD 457,395.63 and IRR of 9.22\%; by applying a 5-year accelerated average depreciation for assets, NPV increases to USD 848,030.3 and IRR to $10.72 \%$ p.a. The research showed that profitability of wind generation projects can be improved, making these investments more attractive, through government action by a) reducing taxes on wind equipment and IRS rates and b) reducing the depreciation period of related equipment/assets and c) offering lower interest rates to finance wind generation projects.

\section{References}

Ahuett-Garza, H., and Kurfess, T., A brief discussion on the trends of habilitating technologies for Industry 4.0 and Smart manufacturing. Manufacturing Letters, 15, 60-63, 2018.

Abeeolica Boletim Técnico ('Technical Bulletin') available at: http://abeeolica.org.br /wpcontent/uploads/2019/03/Infovento_PT.pdf, retrieved 7/04/2019

Amin, Magdy I., El-Samanoudy Feasibility Study of Wind Energy Utilization in Saudi Arabia. Journal of Wind Engineering and Industrial Aerodynamics, Vol 18 pp 153 - 163, 1985.

BRAZILIAN MINISTRY OF MINES AND ENERGY (2018), Installed generation capacity in the Brazilian electricity system - Ministry of Mines and Energy, Technical report.

Effiom S.O., Nwankwojikeb B.N., Abam F.I. Economic cost evaluation on the viability of offshore wind turbine farms in Nigeria. Energy Reports 2, pp. 48-53, 2016.

EPE Participação de Empreendimentos Eólicos nos Leilões de Energia no Brasil. Empresa de Planejamento Energético, Ministério de Minas e Energia, 2018.

Goldenberg, M A Arte de pesquisar: como fazer pesquisa qualitativa em Ciências Sociais ("The art of research: how to do qualitative research in Social Sciences') - Rio de Janeiro: Record, 2011.

GTZ (2002) Feasibility Study of a 19,2 MW Wind Park at Qiyueshan, Lichuan County, Hubei Province, PR China, retrieved 25.7.2011

Khambalkar V.P., Gadge S.R, Dahatonde S.B., KaraleD.S. Wind Energy Cost and feasibility of a 2 MW Wind Power Project. International Energy Journal nr 8, pp. 285-290, 2007.

Komarek, T. M. Economic Feasibility Evaluation of Small Wind Systems in Michigan Agriculture; at file://C:/Users/User/Downloads/TimothyMKomarek.pdf; 2007.

Lakatos, E. M., Marconi, M. A. Fundamentos de metodologia científica ("Fundamentals of Scientific Methodology). São Paulo: Atlas, 1993.

MINISTRY OF ECONOMIC AFFAIRS IN THE NETHERLANDS 'Market study: Wind energy in Brazil', published March ,2014

Oliveira W. S., Fernandes A. J. Cost-effectiveness analysis for wind energy Projects. International Journal of Energy Science, Vol.2 No.1 2011 pp.15-22, 2015.

STATE SECRETARIAT OF INFRASTRUCTURE OF THE STATE OF CEARÁ -SEINFRA - Atlas Eólico e Solar do Estado do Ceara ('Wind and Solar Atlas of the State of Ceara') - published May 2019;

Wind Energy Council GWEC. Global Wind Report Annual Market Update; 2017.

\section{Biographies (Máx 200 palavras por integrante)}


Antonio Henriques de Araujo Junior is a Transportation Engineer, graduated at the German Wuppertaler Bergische University. He got a Master degree in Economics at the University of São Paulo (USP), Brazil and a $\mathrm{PhD}$ degree from the Escola Politecnica (USP), in Production Engineering. He teaches and investigates in Production Engineering related areas at the State University of Rio de Janeiro. He is a reviewer of several international journals in Production Engineering related areas and is an area editor of the Journal of Aerospace Technology and Management (JATM). Dr. Araujo worked many years in the automotive and aeronautical industry.

Nilo Antonio de Souza Sampaio got a PhD in Mechanical Engineering at the Universidade Estadual Paulista (UNESP-FEG), a Master's Degree in Mechanical Engineering at the University of Taubaté (UNITAU) and a university graduate in Chemical Engineer at the University of São Paulo (EEL / USP). He is Adjunct Professor I of the Rio de Janeiro State University and he teaches in the graduation of the courses of Production Engineering, Mechanical Engineering and Chemical Engineering. He works with Mathematics and Statistics, with emphasis on Applications of Statistics and Mathematics in Sciences, Planning of Experiments and Monitoring of Processes. It has several articles published in periodicals and annals of national and international scientific events.

José Glênio Medeiros de Barros is a Mechanical Engineer, graduated at the Rio de Janeiro State University. He got a Master degree in Mechanical Engineering at the Pontifical Catholic University of Rio de Janeiro, Brazil and a PhD degree from the Polytechnic School at the Rio de Janeiro Federal University, in Production Engineering. He teaches and investigates in Production Engineering related áreas at the State University of Rio de Janeiro. Dr. Barros still works as an appraiser of undergraduate courses in industrial engineering and higher education institutions for the Ministry of Education in Brazil.

Maria da Gloria Diniz de Almeida is a Production Engineering, graduated at the Rio de Janeiro State University. She got a Master's degree in Production Engineering at the Federal University of Rio de Janeiro and a $\mathrm{PhD}$ in Mechanical Engineering from the State University of São Paulo "Julio de Mesquita Filho". She is currently an assistant professor at the State University of Rio de Janeiro. He has experience in the area of Production Engineering, with emphasis on Industrial Facilities Planning, working mainly on the following topics: effects analysis, industrial productivity, productivity, cost reduction and ergonomics.

Bernardo Bastos da Fonseca got a $\mathrm{PhD}$ in Production Engineering at the Luiz Alberto Coimbra Institute for Graduate Studies and Engineering Research at the Federal University of Rio de Janeiro - PEP / COPPE / UFRJ. He develops his research in the area of ergonomics, human factors, security, environment and health. He got a Master in Production Engineering with emphasis in Ergonomics and Complex Systems at the COPPE / UFRJ and a MBA in Ergonomics at the COPPE / UFRJ. He is graduated in Industrial Design at the UFRJ and he develops studies in the area of ergonomics with emphasis on complex systems, design, product development, health and safety at work. He developed ergonomic evaluation studies in chemical laboratories, health insurance offices and in a manufacturing company. Currently he teaches and investigates in the Production Engineering the State University of Rio de Janeiro

Luiz de Freitas Ayres holds a degree in Metallurgical Engineering from the Armando Álvares Penteado Foundation (1976) and a Master's degree in Business Administration from Mackenzie Presbyterian University (2007). He served as a part-time professor at Mackenzie Presbyterian University in São Paulo, Brazil and has a 25 years professional experience in Quality Management at Mercedes Benz do Brasil. Currently, he is finishing a Ph.D at the University of Minho, Portugal. 